\section{Is the single use of intraoperative 5 -fluorouracil in filtering surgery for high-risk cases enough?}

\begin{abstract}
Purpose To study the efficacy of the adjunctive use of a single intraoperative application of 5-fluorouracil (5FU) in eyes with poor prognoses for a successful outcome with a trabeculectomy.

Method Twenty-four patients (25 eyes) with a mean age of $63.7 \pm 14.7$ years (range 27-86 years) and a history of one or more risk factors (age $<50$ years, more than 3 years on topical medication, a previous failed filter, previous cataract surgery, uveitis, neovascular glaucoma) underwent trabeculectomy with the intraoperative application of $5 \mathrm{FU}$ on a sponge $(25 \mathrm{mg} / \mathrm{ml})$ for $5 \mathrm{~min}$. The average follow-up was $10.1 \pm 5.5$ months.

Results The mean pre-operative intraocular pressure (IOP) was $24.7 \pm 6.2 \mathrm{mmHg}$ and the mean post-operative IOP was $13.9 \pm 3.5 \mathrm{mmHg}$. Success, defined as an IOP within desired target levels for a particular eye, in the presence of a functioning filter, without supplementary medical therapy, was achieved in $56.5 \%$ of cases.

Conclusions Our results of successful filters in this group of patients with moderate- to highrisk characteristics approach similar figures quoted for trabeculectomies without the adjunctive use of intraoperative $5 \mathrm{FU}$ in eyes with poor prognoses with a similar length of follow-up. Though the numbers are small there is a trend that indicates that the intraoperative application of a single dose of $5 \mathrm{FU}$ alone may not be sufficient in eyes with moderate- to high-risk characteristics of failure of a trabeculectomy.
\end{abstract}

Key words 5-Fluorouracil, Trabeculectomy

\footnotetext{
P. Watts

N. Karia

J. McAllister

Prince Charles Eye Unit King Edward VII Hospital Windsor SL4 3DP, UK

P. Watts

58 Crystal Wood Road

Cardiff CF4 4HW, UK
}

PATRICK WATTS, NIRAL KARIA, JAMES MCALLISTER inhibition of thymidilate synthetase and its incorporation into the RNA molecule, has improved the success rate of filtering surgery. ${ }^{6,7}$

Initially the route of administration was by twice-daily injections during the first week after filtering surgery and once-daily injections during the second week; ${ }^{8}$ the frequency of administration was subsequently reduced with no apparent reduction in the success rate. ${ }^{9}$ This method of administration is painful, involves a number of post-operative visits, is associated with significant corneal epithelial toxicity and has an increased incidence of post-operative wound leak. ${ }^{8,10}$ A single intraoperative application of 5FU at the site of filtering surgery largely avoids the above problems associated with post-operative injections and is presently the current practice. The initial results reported are encouraging. ${ }^{11}$

We present our initial experience with the single intraoperative application of 5FU in patients with low/moderate- to high-risk characteristics for filtering surgery failure.

\section{Materials and methods}

Twenty-four consecutive patients (25 eyes) were recruited for this study between 1993 and 1995 (both the eyes of patient 8 were included). Inclusion criteria were uncontrolled glaucoma on maximally tolerated medical therapy and low / moderate- to high-risk factors for failure of filtering surgery. Exclusion criteria were previous filtering surgery with the use of an antimetabolite or post-operative 5FU injections.

The risk factors are outlined in Table 1. A stratification of risk factors into high-risk (major) and low-risk (minor) was chosen as it is patients in the high-risk group who have a poor prognosis for successful filtering surgery. ${ }^{12}$ All the pseudophakic patients included had conjunctival incisional surgery. A previous similar classification of risk factors has been used by Lanigan et al. ${ }^{11}$ The demographic characteristics of the patients are listed in Table 2, which includes both eyes of patient 8 . 
Table 1. Risk factors for filtering surgery

\begin{tabular}{lr}
\hline Main risk factors & \\
Uveitis & 1 \\
Neovascular glaucoma & 1 \\
Previous trabeculectomy & 14 \\
Pseudophakia & 9 \\
Minor risk factors & \\
Age less than 50 years & 4 \\
Afro-Caribbean/Asian origin & 2 \\
More than 3 years on topical medications & 17 \\
\hline
\end{tabular}

Low risk: One or two minor risk factors.

Moderate risk: Three minor risk factors.

High risk: Presence of any of the major factors.

A trabeculectomy was performed (by P. W. and J. M.) as described elsewhere, ${ }^{13}$ with a limbal-based conjunctival flap and a scleral flap $4 \mathrm{~mm} \times 4 \mathrm{~mm}$ in size. The 5FU (David Bull Laboratories, Warwick, UK) was applied on sponges to both sides of the dissected scleral flap (sandwich technique), before the anterior chamber was entered. The sponges (microsponge, Alcon), cut freehand, measured about $5 \mathrm{~mm} \times 2 \mathrm{~mm} \times 1 \mathrm{~mm}$ when soaked with the 5FU solution. The concentration used was $25 \mathrm{mg} / \mathrm{ml}$. The top sponge was resoaked every minute and reapplied for a total time of 5 min, taking care not to touch the free cut edge of the conjunctiva. The area was washed with $10 \mathrm{ml}$ of balanced salt solution (Alcon) then dried, and the trabeculectomy completed with a $2 \mathrm{~mm} \times 2 \mathrm{~mm}$ block of trabecular tissue excised freehand. A peripheral iridectomy was performed and the scleral flap closed with an average of two 10-0 nylon interrupted sutures depending on the number necessary to keep the anterior chamber formed. The conjunctival incision was closed with an 8-0 continuous Vicryl suture. A subconjunctival injection of betamethasone and

Table 2. Demographic characteristics of the patients and summary of the results

\begin{tabular}{|c|c|c|c|c|c|c|c|c|}
\hline $\begin{array}{l}\text { Patient } \\
\text { no. }\end{array}$ & Age/Sex & Race & Diagnosis & $\begin{array}{l}\text { Pre-op. IOP } \\
(\mathrm{mmHg})\end{array}$ & $\begin{array}{l}\text { Post-op. IOP } \\
\quad(\mathrm{mmHg})\end{array}$ & Medication & $\begin{array}{l}\text { Post-op. } \\
\text { medication }\end{array}$ & Risk factors \\
\hline 1 & $76 / F$ & $\mathrm{C}$ & CACG & 21 & 16 & 2 & 2 & $\begin{array}{l}\text { Failed trabeculectomy, pseudophakia, } \\
>3 \text { years on topical medication }\end{array}$ \\
\hline 2 & $56 / \mathrm{M}$ & C & POAG & 23 & 19 & 4 & 4 & $\begin{array}{l}\text { Two failed trabeculectomies, }>3 \text { years on } \\
\text { topical medication }\end{array}$ \\
\hline 3 & $69 / \mathrm{M}$ & C & SOAG & 48 & 18 & 2 & 1 & Pseudophakia, vitrectomy \\
\hline 4 & $86 / F$ & $\mathrm{C}$ & POAG & 20 & 15 & 2 & 2 & $\begin{array}{l}\text { Pseudophakia, failed trabeculectomy, } \\
>3 \text { years on topical medication }\end{array}$ \\
\hline 5 & $82 / F$ & C & POAG & 24 & 18 & 3 & 1 & $\begin{array}{l}\text { Two failed holmium laser sclerostomies, } \\
>3 \text { years on topical medication }\end{array}$ \\
\hline 6 & $79 / \mathrm{M}$ & $\mathrm{C}$ & POAG & 22 & 12 & 2 & 0 & $\begin{array}{l}\text { Failed holmium laser sclerostomy, } \\
>3 \text { years on topical medication }\end{array}$ \\
\hline 7 & $86 / F$ & $\mathrm{C}$ & POAG & 22 & 17 & 2 & 1 & $\begin{array}{l}\text { Pseudophakia, }>3 \text { years on topical } \\
\text { medication }\end{array}$ \\
\hline 8 & $67 / \mathrm{M}$ & $\mathrm{C}$ & POAG & 26 & 15 & 3 & 0 & $\begin{array}{l}\text { Failed trabeculectomy, }>3 \text { years on } \\
\text { topical medication }\end{array}$ \\
\hline 8 & $67 / M$ & C & POAG & 21 & 10 & 3 & 0 & $\begin{array}{l}\text { Failed trabeculectomy, }>3 \text { years on } \\
\text { topical medication }\end{array}$ \\
\hline 9 & $59 / \mathrm{M}$ & $\mathrm{C}$ & CACG & 28 & 17 & 3 & 3 & Failed trabeculectomy \\
\hline 10 & $61 / \mathrm{M}$ & $\mathrm{C}$ & POAG & 24 & 9 & 2 & 0 & $\begin{array}{l}\text { Failed trabeculectomy, }>3 \text { years on } \\
\text { topical medication }\end{array}$ \\
\hline 11 & $71 / \mathrm{M}$ & $\mathrm{C}$ & POAG & 19 & 15 & 2 & 0 & $\begin{array}{l}\text { Pseudophakia, }>3 \text { years on topical } \\
\text { medication }\end{array}$ \\
\hline 12 & $39 / \mathrm{M}$ & C & POAG & 27 & 8 & 3 & 0 & $\begin{array}{l}\text { Age }<50 \text { years, }>3 \text { years on topical } \\
\text { medication }\end{array}$ \\
\hline 13 & $76 / \mathrm{M}$ & C & SOAG & 26 & 14 & 2 & 3 & Pseudophakia, vitrectomy \\
\hline 14 & $71 / \mathrm{M}$ & C & NVG & - & - & 2 & - & Neovascular glaucoma \\
\hline 15 & $65 / F$ & A & POAG & 28 & 8 & 2 & 0 & Asian \\
\hline 16 & $49 / F$ & C & POAG & 24 & 8 & 2 & 0 & Age $<50$ years \\
\hline 17 & $55 / \mathrm{M}$ & C & POAG & 21 & 12 & 3 & 0 & $\begin{array}{l}\text { Failed trabeculectomy, }>3 \text { years on } \\
\text { topical medication }\end{array}$ \\
\hline 18 & $52 / \mathrm{M}$ & C & POAG & 31 & 11 & 2 & 2 & $\begin{array}{l}\text { Pseudophakia, failed trabeculectomy, } \\
\text { penetrating corneal graft, }>3 \text { years on } \\
\text { topical medication }\end{array}$ \\
\hline 19 & $50 / \mathrm{M}$ & C & SOAG & 38 & - & 2 & 2 & Pseudophakia, uveitis \\
\hline 20 & $74 / F$ & C & POAG & 32 & 18 & 2 & 0 & $\begin{array}{l}\text { Failed holmium sclerostomy, failed } \\
\text { trabeculectomy, }>3 \text { years on topical } \\
\text { medication }\end{array}$ \\
\hline 21 & $74 / F$ & A & POAG & 20 & 12 & 2 & 0 & $\begin{array}{l}\text { Pseudophakia, }>3 \text { years on topical } \\
\text { medication }\end{array}$ \\
\hline 22 & $61 / \mathrm{M}$ & C & POAG & 21 & 15 & 1 & 0 & Failed trabeculectomy, Asian \\
\hline 23 & $41 / \mathrm{M}$ & C & POAG & 20 & 18 & 2 & 0 & $\begin{array}{l}\text { Failed trabeculectomy, age }<50 \text { years, } \\
>3 \text { years on topical medication }\end{array}$ \\
\hline 24 & $27 / \mathrm{M}$ & C & POAG & 22 & 16 & 2 & 2 & Age $<50$ years \\
\hline
\end{tabular}

C, Caucasian; A, Asian; POAG, primary open angle glaucoma; CACG, chronic angle closure glaucoma; SOAG, secondary open angle glaucoma; NVG, neovascular glaucoma; IOP, intraocular pressure. 
cefuroxime was given at the end of the procedure and a drop of atropine $1 \%$ instilled.

Follow-up visits were on day 1 , week 1 , week 2 , week 4, 2 months and 6 months post-operatively. Additional visits were dictated by the condition of the patient.

The post-operative regimen of drops included a steroid antibiotic combination (dexamethasone, neomycin and polymixin B sulphate) for 2 weeks followed by a tapering dose of dexamethasone for 12 weeks post-operatively.

Success was defined as complete or qualified. Complete success was an intraocular pressure that was considered safe for that particular optic nerve (target pressure), without supplementary medical therapy, in the presence of a functioning filter. Qualified success was as above but with the help of supplementary medical therapy.

\section{Results}

Of the 24 patients, one was lost to follow-up (patient 14) and another was excluded as he received supplementary post-operative 5FU injections (patient 19). Hence 23 eyes that received a single intraoperative dose of $5 \mathrm{FU}$ were included in the analysis of the data. The mean age of the patients was $63.7 \pm 14.7$ years (range $27-86$ years). The mean pre-operative IOP was $24.7 \pm 6.2 \mathrm{mmHg}$ and the mean post-operative IOP was $13.9 \pm 3.5 \mathrm{mmHg}$. The number of pre-operative medications received was $2.3 \pm 0.61$ and the mean supplementary medical therapy received was $0.96 \pm 1.2$. Thirteen eyes $(13 / 23 ; 56.5 \%)$ were complete successes; a further eye was a qualified success. The mean duration of follow-up was $10.1 \pm 5.5$ months (range 3-24 months). The patients maintained the level of pre-operative visual acuity and visual fields throughout follow-up.

The post-operative complications included a shallow anterior chamber $(\mathrm{AC})$ in one patient, a flat $\mathrm{AC}$ without keratolenticular contact, wound leak in two patients, early hypotony in two patients, and $<2 \mathrm{~mm}$ hyphaemas in two patients. All these complications resolved with conservative management (Table 3).

Both the patients in the low-risk category were successes; one patient ( 1 of 2 eyes) in the moderate-risk group failed. Nine eyes ( 9 of 19 eyes) in the high-risk group were successful (47.3\%). The Kaplan-Meier survival estimates demonstrate the probability of successful IOP control after intraoperative use of 5FU during a trabeculectomy (Fig. 1).

Table 3. Post-operative complications

\begin{tabular}{ll}
\hline Shallow anterior chamber & 1 \\
Flat anterior chamber (no keratolenticular contact) & 1 \\
Wound leak & 2 \\
Early hypotony & 2 \\
Hyphaema & 2 \\
\hline
\end{tabular}

\section{Discussion}

The introduction of post-operative subconjunctival injections of 5FU has improved the success rate of filtering surgery in high-risk patients. ${ }^{12,14-16}$ The optimal route of administration, however, seems to be a single intraoperative application of $5 \mathrm{FU}$ on a sponge. It offers several advantages over the injections, in that it avoids multiple post-operative visits, there is no pain associated with its application, the corneal epithelium is unaffected and wound leaks are uncommon. In addition the drug is delivered at the site where it is required to offset the fibrosis associated with failure. The drawback of a single intraoperative application of $5 \mathrm{FU}$ on a sponge is that the dose cannot be measured or titrated. ${ }^{11}$

The initial results reported by Lanigan et al. ${ }^{11}$ were encouraging, with a success rate of $91 \%(100 \%$ if the results of only the low- to moderate-risk category were considered) with a limited follow-up (of 3-9 months). In the first year of follow-up of the Fluorouracil Filtering Surgery Study (FFSS) there was a 73\% success rate in patients with moderate- to high-risk characteristics, compared with a $50 \%$ success rate for the control group. ${ }^{14}$

The success rate in the group of patients presented here was $56.5 \%$ (60.8\% qualified successes were included) over a follow-up ranging from 3 to 24 months (mean $10.1 \pm 5.5$ months). If our two low-risk category patients were excluded the success rate was $47.3 \%$ $(9 / 19)$. This is similar to the controls of the FFSS group with comparable lengths of follow-up. This trend from our study seems to suggest that the single application of intraoperative 5FU offers no advantage in the moderateto high-risk category. The results are at odds with previous studies (Table 4), which may be explained by the differing risk categories, different lengths of followup, and differing criteria for success.

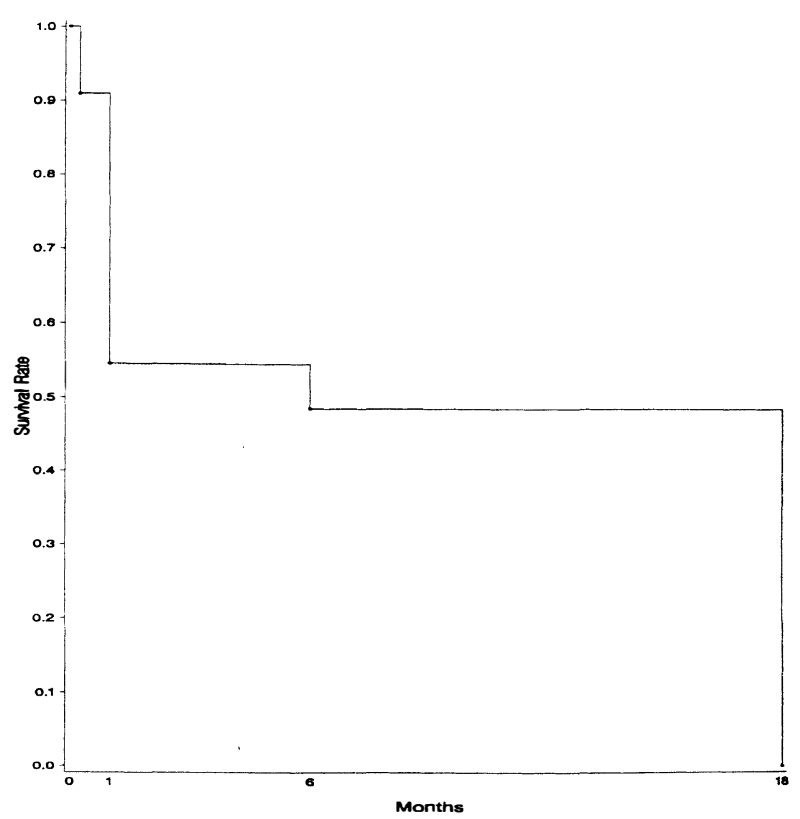

Fig. 1. Estimated probability of survival of successful IOP control (Kaplan-Meier survival estimates) in moderate- to high-risk cases. 


\begin{tabular}{|c|c|c|c|c|c|c|}
\hline \multirow[b]{2}{*}{ Authors } & \multirow[b]{2}{*}{ Year } & \multirow{2}{*}{$\begin{array}{c}\text { Route of } \\
\text { administration }\end{array}$} & \multirow{2}{*}{$\begin{array}{c}\text { No. of patients } \\
\text { (risk) }\end{array}$} & \multicolumn{2}{|c|}{ Success rate } & \multirow[b]{2}{*}{ Follow-up } \\
\hline & & & & $5 F U$ & Controls & \\
\hline Smith et al. ${ }^{24}$ & 1992 & Sponge $(50 \mathrm{mg} / \mathrm{ml})+$ injections & 14 (7 low, 7 high) & $93 \%$ & - & 6.4 months \\
\hline Lanigan et al. ${ }^{11}$ & 1994 & Sponge $(25 \mathrm{mgl} / \mathrm{ml})$ & 33 (low/high) & $91 \%$ & - & 5.7 months \\
\hline Mora et al. ${ }^{17}$ & 1996 & Sponge $(50 \mathrm{mg} / \mathrm{ml})+$ injections & 119 (low / high) & $86.4 \%$ & - & 16.0 months \\
\hline Singh et al. ${ }^{18}$ & 1997 & Sponge $(50 \mathrm{mg} / \mathrm{ml})$ & 37 (low) & $73 \%$ & - & 3 months \\
\hline Bell et al. ${ }^{19}$ & 1997 & Sponge $(25 \mathrm{mg} / \mathrm{ml})+$ injections & 45 (low/moderate/high) & $80 \%$ & - & 24 months \\
\hline Ruderman et al. ${ }^{25}$ & 1987 & Injections (45 mg) & 14 (high) & $85 \%$ & $25 \%$ & 12 months \\
\hline Ophir et al. ${ }^{21}$ & 1992 & Injection (20-30 mg) & 41 (low) & $96 \%$ & $76 \%$ & 17.5 months \\
\hline FFSS $^{14}$ & 1989 & Injections (105 mg) & 105 (high) & $73 \%$ & $50 \%$ & 1 year \\
\hline FFSS $^{15}$ & 1993 & Injections (105 mg) & 100 (high) & $51 \%$ & $26 \%$ & 3 years \\
\hline FFSS $^{16}$ & 1996 & Injections (105 mg) & 105 (high) & $49 \%$ & $26 \%$ & 5 years \\
\hline
\end{tabular}

Mora et al. ${ }^{17}$ reported a success rate of $86.4 \%$. The shortest length of follow-up was 2 months, the concentration of $5 \mathrm{FU}$ was $50 \mathrm{mg} / \mathrm{ml}$ and the majority of eyes received an average of 5.3 supplementary $5 \mathrm{FU}$ injections post-operatively, which may explain the improved success rate.

In a black population from Ghana, Singh et al. ${ }^{18}$ reported a success rate of $73 \%$ (IOP $<21 \mathrm{mmHg}$ ). This differs from our population group, in addition to the fact that the concentration of $5 \mathrm{FU}$ was $50 \mathrm{mg} / \mathrm{ml}$ and the technique of application differed slightly.

Bell et al. ${ }^{19}$ reported a success rate of $80 \%$ on or off supplementary medical therapy, with no difference between the high- or low-risk groups, with a mean follow-up of 24 months. If only the complete successes were considered, the percentage dropped to $48.8 \%$. Amongst the complete successes there were 8 of 11 patients ( $73 \%$ success rate) in the low/moderate-risk groups (our classification) and 14 of 34 (41.1\% success rate) in the high-risk category. The latter figures do correlate with the figures in our high-risk category. This study differs from ours in that the authors used postoperative 5FU injections if there were signs of bleb failure, and the technique of application was slightly different in that the 5FU was applied before the scleral dissection.

The 5 year follow-up of the FFSS recently reported a further drop-off in the success rate, and at the end of the study period $49 \%$ of eyes maintained successful filters compared with $26 \%$ in the control group. ${ }^{16}$ It is possible that the percentage of successful cases in our series will fall with a longer follow-up.

Though not comparable in terms of mode of 5FU application, when the results for the first year of the FFSS are compared with those of our study, it would seem reasonable to suggest that the dose delivered by a single intraoperative application of $5 \mathrm{FU}$ on a sponge is insufficient to improve the success rate of filtering surgery in patients who present with high-risk characteristics.

It is not known whether a higher concentration of the drug ( $50 \mathrm{mg} / \mathrm{ml}$; not commerically available in the UK) would offer any advantage over the $25 \mathrm{mg} / \mathrm{ml}$ concentration. Khaw et al..$^{20}$ have shown that a very short exposure (5 min) of human Tenon's capsule fibroblasts to
5FU restricted the increase in the number of cells for long periods and hence a single application at the time of surgery should negate the need for repeated postoperative injections. It could be postulated either that high-risk patients have an increased resident population of fibroblasts whose outgrowth is not sufficiently suppressed by the single intraoperative application of $5 \mathrm{FU}$ or that the duration of suppression in this group is not adequate.

Ophir et al. ${ }^{21}$ reported a successful result in $96 \%$ of their patients with no risk factors who received adjunctive 5FU injections, with an average follow-up period of 17.5 months; the success rate in controls was $76 \%$. These results are similar to figures presented for the use of intraoperative 5FU application in low- to moderate-risk groups. ${ }^{11}$ Though these groups are not strictly comparable (Table 4), the conclusion one could draw from them and our study is that the single use of 5 FU intraoperatively may prolong the survival of filtering procedures in patients with either no risk factors or low to moderate risk factors.

The use of intraoperative 5FU at best achieves a reversible delay of fibroblast proliferation; animal studies suggest that this may be as short as 1 week. ${ }^{22}$ Hence the patients with high-risk characteristics may require a 'fibrocidal' antimetabolite such as mitomycin $\mathrm{C}^{23}$ or prolonged administration of $5 \mathrm{FU}$ injections in addition to the dose applied intraoperatively on a sponge. Smith et al. ${ }^{24}$ reported a success rate of $93 \%$ in a mixed group of patients who received adjunctive $5 \mathrm{FU}$ on a sponge together with post-operative injections; however, this regime negates some of the advantages offered by a single intraoperative application, except that the number of post-operative injections may be reduced.

\section{Conclusion}

This small group of patients with a reasonable follow-up period demonstrate a trend that a single intraoperative application of 5FU on a sponge is insufficient alone to enhance the success of filtering surgery in patients with high-risk characteristics. 


\section{References}

1. Teng CC, Chi HH, Katzin HM. Histology and mechanism of filtering operations. Am J Ophthalmol 1959;47:16-34.

2. Addick EM, Quigley HA, Green WR, Robin AL. Histological characteristics of filtering blebs in glaucomatous eyes. Arch Ophthalmol 1983;101:795-8.

3. Maumenee AE. External filtering operations for glaucoma: the mechanisms of function and failure. Trans Am Ophthalmol Soc 1960;58:319-28.

4. Skuta GL, Parrish RK II. Wound healing in glaucoma filtering surgery. Surv Ophthalmol 1987;32:149-70.

5. Jampel HD, McGuigan LJB, Dunkelberger GR, et al. Cellular proliferation after experimental glaucoma filtering surgery. Arch Ophthalmol 1988;106:89-94.

6. Hartzer M, Daily N, Blumenkranz MS. Ocular pharmacology of fluoropyrimidines: mechanism of action of 5FU. Invest Ophthalmol Vis Sci 1987;28(Suppl)75.

7. Lee DA, Tehrani ST, Kitada S. The effect of 5-fluorouracil and cytarabine on human fibroblasts from the Tenon's capsule. Invest Ophthalmol Vis Sci 1990;31:1848-58.

8. Heuer DK, Parrish RK, Gressel MG, Hodapp E, Palmberg PF, Anderson D. 5-Fluorouracil and glaucoma filtering surgery. II. A pilot study. Ophthalmology 1984;91:384-94.

9. Rabowsky JH, Ruderman JM. Low-dose 5-fluorouracil and glaucoma filtering surgery. Ophthalmic Surg 1989;20:347-9.

10. Lee DA, Hersh P, Kersten D, Melamed S. Complications of subconjunctival 5-fluorouracil following glaucoma filtering surgery. Ophthalmic Surg 1987;18:187-90.

11. Lanigan L, Sturmer J, Baez KA, Hitchings RA, Khaw PT. Single intraoperative applications of 5-fluorouracil during filtering surgery: early results. Br J Ophthalmol 1994;78:33-7.

12. Heuer DK, Parrish RK, Gressel MG, Hodapp E, Desjardins DC, Skuta GL, et al. 5-Fluorouracil and glaucoma filtering surgery. III. Intermediate follow-up of a pilot study. Ophthalmology 1986;93:1537-46.

13. Cairns JE. Trabeculectomy. Am J Ophthalmol 1968;66:673-9.

14. The Fluorouracil Filtering Surgery Study Group. Fluorouracil Filtering Surgery Study: One year follow-up. Am J Ophthalmol 1989;108:625-35.
15. The Fluorouracil Filtering Surgery Study Group. Three-year follow-up of the Fluorouracil Filtering Surgery Study. Am J Ophthalmol 1993;115:82-92.

16. The Fluorouracil Filtering Surgery Study Group. Five-year follow-up of the Fluorouracil Filtering Surgery Study. Am J Ophthalmol 1996;121:349-66.

17. Mora JS, Nguyen N, Iwach AG, et al. Trabeculectomy with intraoperative sponge 5-fluorouracil. Ophthalmology 1996;103:963-70.

18. Singh $K$, Egbert $P$, Byrd S, et al. Trabeculectomy with intraoperative 5-fluorouracil vs mitomycin C. Am J Ophthalmol 1997;123:48-53.

19. Bell RWD, Habib NE, O'Brien C. Long-term results and complications after trabeculectomy with a single peroperative application of 5 FU. Eye 1997;11:663-71.

20. Khaw PT, Sherwood MB, Mackay SL, et al. Five minute treatments with fluorouracil, floxuridine and mitomycin have long term effects on human Tenon's capsule fibroblasts. Arch Ophthalmol 1992;110:1150-4.

21. Ophir A, Ticho U. A randomised study of trabeculectomy and subconjunctival administration of fluorouracil in primary glaucomas. Arch Ophthalmol 1992;110:1072-5.

22. Khaw PT, Doyle JW, Sherwood MB, Grierson I, Shultz G, McGorray S. Prolonged localised tissue effects from 5-minute exposures to fluorouracil and mitomycin C. Arch Ophthalmol 1993;111:263-7.

23. Kitazawa Y, Kawase K, Matsushita H, Minobe M. Trabeculectomy with mitomycin: a comparative study with fluorouracil. Arch Ophthalmol 1991;109:1693-8.

24. Smith MF, Sherwood MB, Doyle W, Khaw PT. Results of intraoperative 5-fluorouracil supplementation on trabeculectomy for open-angle glaucoma. Am J Ophthalmol 1992;114:737-41.

25. Ruderman JM, Welch DB, Smith MF, Shoch DE. A randomised study of 5-fluorouracil and filtering surgery. Am J Ophthalmol 1987;104:218. 